\title{
ОБЛАСНА НАУКОВО-ПРАКТИЧНА КОНФЕРЕНЦІЯ «АКТУАЛЬНІ ПИТАННЯ ІНФЕКЦІЙНИХ ЗАХВОРЮВАНЬ У ДІТЕЙ» З НАГОДИ 95-РІЧЧЯ ХАРКІВСЬКОЇ МЕДИЧНОЇ АКАДЕМІї ПІСЛЯДИПЛОМНОЇ ОСВІТИ ТА 25-РІЧЧЯ КАФЕДРИ ДИТЯЧИХ ІНФЕКЦІЙНИХ ХВОРОБ
}

\author{
Харківська медична академія післядипломної освіти, Україна
}

\begin{abstract}
Наведено коротку інфрормацію про науково-практичну конференцію «Актуальні питання інфекційних захворювань у дітей» з нагоди 95-річчя Харківської медичної академії післядипломної освіти та 25-річчя кафредри дитячих інфекційних хвороб, яка відбулася 13 березня 2018 р. у Харкові.
\end{abstract}

Ключові слова: науково-практична конореренція, інфекційні захворювання у дітей.

13 березня 2018 р. у м. Харкові відбулася обласна науково-практична конференція з нагоди 95-річчя Харківської медичної академії післядипломної освіти (ХМАПО) та 25-річчя кафедри дитячих інфекційних хвороб ХМАПО «Актуальні питання інфекційних захворювань у дітей».

3 вітальним словом до учасників конференції звернулися проректор з наукової роботи ХМАПО профр. М.А. Георгіянц, заступник начальника Управління охорони здоров'я Харківської обласної державної адміністрації Г.М. Сіроштан, голова Харківської обласної асоціації інфекціоністів України проф. П.В. Нартов.

Аналіз роботи кафедри за 25 років здійснила завідувач кафредри дитячих інфекційних хвороб ХМАПО проф. Л.А. Ходак.

Самостійна кафедра дитячих інфекційних хвороб була заснована у лютому 1993 р., коли ця патологія стала лікарською спеціальністю. Завідувачем був призначений доц. К.К. Макаренко, який зробив великий внесок в організацію кафедри, визначив ії науковий напрям. 32000 р. кафедру очолює д. мед. наук, проф. Л.А. Ходак. На кафедрі працюють 3 доценти (Т.І. Навєт, В.А. Міщенко, В.Д. Макаренко), один асистент (В.І. Браілко), клінічний ординатор та 2 лаборанти.

Касредра дитячих інфрекційних хвороб однією з перших в Україні займається проблемою вивчення герпесвірусних інфекцій, особливо обумовлених ними уражень нервової системи. На цю тему захищено 2 докторські та 9 кандидат- ських дисертацій. Спільно з інститутом неврології, психіатрії НАМН України проводилася планова науково-дослідна робота, присвячена вивченню герпесвірусів у розвитку розсіяного склерозу. Також одним 3 наукових напрямків кафедри стало визначення внутрішньоклітинних збудників в індекційній патології у дітей. Вагомим свідченням цього $€$ наявність 8 авторських свідоцтв на винахід та 5 патентів України.

Співробітниками кафедри представлено наукові праці на фрорумах різних рівнів (міжнародних симпозіумах, національних конгресах, з'їздах, науково-практичних конференціях). Проф. Л.А. Ходак $є$ членом спеціалізованої вченої Ради із захисту докторських і кандидатських дисертацій при ХМАПО. Співробітники кафредри є авторами методичних рекомендацій (18), навчально-методичних посібників (15), 6 монографрій, у тому числі однієї англійською мовою, 5 розділів в двох національних підручниках.

Основною діяльністю кафедри є навчальний процес. щорічно на циклах тематичного удосконалення, спеціалізації та передатестаційному циклі підвищують свій профресійний рівень 300-400 лікарів різних спеціальностей (дитячі інфекціоністи, педіатри, інфекціоністи, неврологи, дитячі неврологи, лікарі загальної практики-сімейної медицини, неонатологи, акушери-гінекологи). 2-3 рази на рік проводяться виїзні цикли.

32004 р. кафедра проводить тримісячну спеціалізацію з дитячих інфекцій для педіатрів. За цей період 96 лікарівфахівців отримали сертифікат дитячого інфекціоніста. Великим попитом користуються цикли «TORCH-інфекції у дітей» та «Нейроінфекції»».

Співробітники кафедри тісно співпрацюють 3 клінічною базою, підвищують рівень діагностично-лікувальної допомоги дітям з інсрекційною патологією, впроваджуючи свої наукові розробки в практику.

На конференції виступили провідні фрахівці в галузі інфрекційних хвороб та педіатрії. 
Велику зацікавленість аудиторії викликала доповідь профр. кафредри дитячої анестезіології та інтенсивної терапії ХМАПО М.А. Георгіянц, присвячена проблемі антибіотикорезистентності збудників внутрішньолікарняних інсрекцій у відділеннях інтенсивної терапії. Було обґрунтовано необхідність моніторингу антибіотикорезистентності та побудови на підставі його результатів стратегії раціональної антибактерійної терапії. Продемонстровано результати 3 вивчення чутливості мікросрлори у відділенні інтенсивної терапії Харківської обласної дитячої інфрекційної клінічної лікарні (ХОДІКЛ) та вибору ефективних антибактерійних препаратів.

Доповідь завідувача кафедри дитячої анестезіології та інтенсивної терапії ХМАПО проф. В.А. Корсунова була присвячена актуальним питанням менінгококової інсрекції, її минулому та майбутньому. Він продемонстрував еволюцію підходів до антибактерійної терапії, респіраторної та гемодинамічної підтримки, застосування глюкокортикоїдів. Також був проведений огляд перспективних напрямків інтенсивної терапії. Наприкінці доповіді профр. В.А. Корсунов продемонстрував динаміку значення летальності від менінгококової інфекції у відділенні інтенсивної терапії ХОДІКЛ за 25 років.

Дуже цікаву доповідь «Діарейний синдром на етапі реконвалесценції очима дитячого гастроентеролога» представила завідувач кафедри педіатричної гастроентерології та нутріціології ХМАПО проф. О.Ю. Бєлоусова. Вона зазначила, що ВООЗ рекомендує широке використання оральної регідратації з використанням регідрону, велике значення має дієта, перевагу варто віддавати сорбентам на основі білої глини та звернула увагу на обережне ставлення до пробіотиків.

Професор 3.В. Єлоєва, завідувач кафредри педіатрії ХМАПО, свою доповідь присвятила актуальному питанню - персистуючим інсекціям, які при тривалому перебігу можуть викликати маніфестацію хронічних соматичних захворювань. Велику увагу приділено внутрішньоклітинним збудникам: хламідіям, мікоплазмам, герпесвірусам. В основі соматичної патології, як правило, лежить автоімунний механізм розвитку.

Як експерт $з$ питань вакцинації з доповіддю на тему «Погляд педіатра на проблему імунопрофрілактики» виступила завідувач кафедри поліклінічної педіатрії ХМАПО проф. О.А. Цодікова. В її доповіді було представлено стратегічні напрями імунопрофрілактики, наголошено на причинах, що породжують у людей недовіру до вакцинації, висвітлено стан справ з вакцинацією за кордоном. Головною метою доповіді було донести присутнім об'єктивну інорормацію про ефрективність профрілактичних щеплень, повернути втрачену довіру до імунопрофрілактики, залучення медичних працівників і батьків до усвідомленого рішення вакцинувати дітей. Проф. О.А. Цодікова поділилась досвідом відкриття в дитячих поліклініках м. Харкова «шкіл імунізації», в яких за активної участі науковців ХМАПО консультуються батьки з питань імунізації, проводиться роз'яснювальна робота в родинах щодо важливості профрілактики інфекційних захворювань.

Проф. К.В. Юрко (кафедра інфекційних хвороб ХНМУ) навела дані про актуальність HCV-інфекції в Україні та світі.

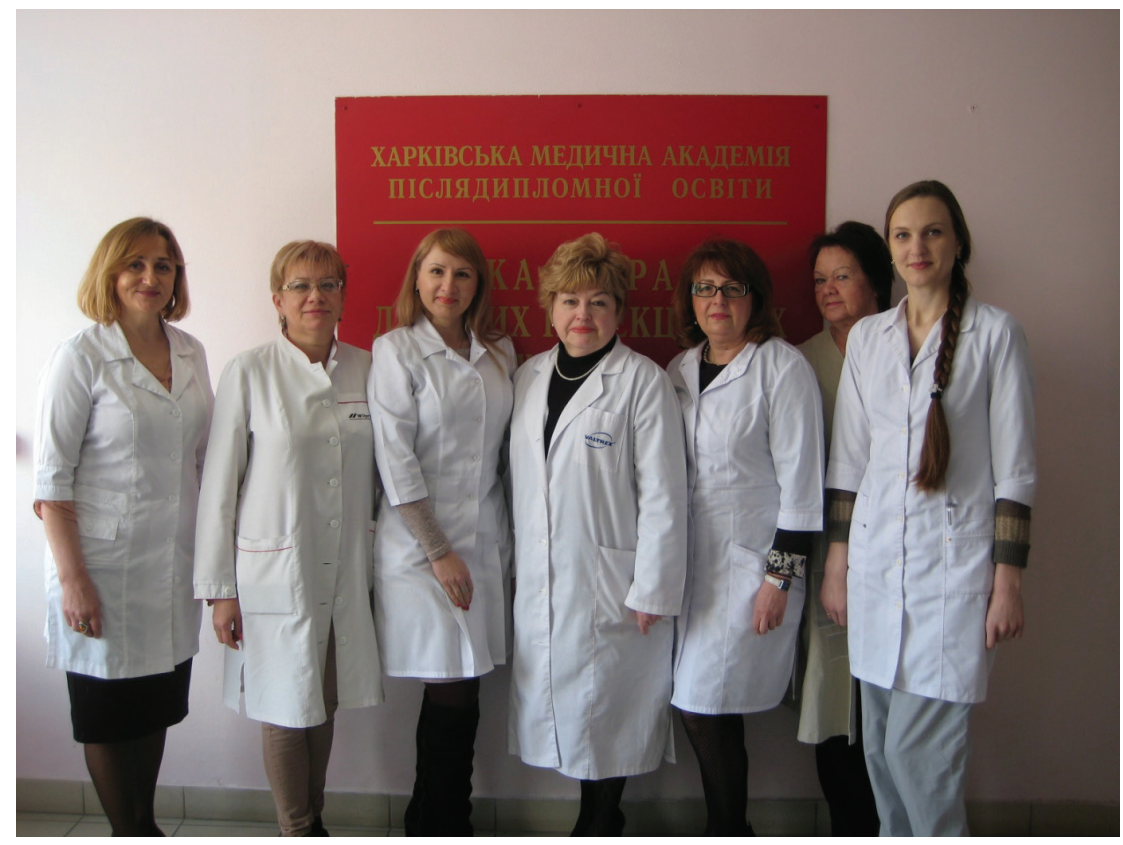

Колектив кафредри дитячих інфекційних хвороб ХМАПО. 
Представлено інформацію про переваги противірусних препаратів прямої дії (ПППД) над інтерфероновими схемами. Поява ПППД привела до революційних змін в терапії хворих на хронічний гепатит С і розширила показання лікування пацієнтів, які раніше не мали шансів (які мали протипоказання до інтерферонових схем або яким терапія проводилась, але була неефективною).

Вдалий досвід використання безінтерферонових препаратів вселяє оптимізм і дозволяє з надією дивитись на перспективу ширшого застосування комбінації ПППД в терапії хворих на хронічний гепатит С.

Профр. Л.А. Ходак, ас. кафедри дитячих інфекційних хвороб В.І. Браілко в своїй доповіді порушили проблему менінгоенцефалітів у дітей. Автори представили аналіз етіологічної структури менінгоенцесалітів за останні 10 років (за даними ХОДІКЛ), зупинились на клініко-інструментальних діагностичних критеріях та особливостях перебігу менінгоенцефралітів у дітей залежно від етіології, звернули увагу на вислід захворювання залежно від термінів призначення специсрічної противірусної терапії. Також було наголошено на важливості проведення МРТ-дослідження на апаратах з високою роздільною здатністю для визначення морфологічних змін головного мозку.

В доповіді проф. С.В. Кузнєцова і ас. Є.С. Ольховського представлена інформація про розповсюдженість ешерихіозної інсрекції, особливостях перебігу хвороби залежно від етіологічного чинника і віку хворих, визначена епідеміологічна ситуація ешерихіозу в Україні і в світі. Надана інформація щодо особливостей перебігу у дітей раннього віку, інфрікованих вірусом Епштейна-Барр, що призводить до подовжання перебігу хвороби і більш тривалого перебування хворих у стаціонарі.

На актуальній проблемі сьогодення - стрептококовій інфекції, особливо її інвазивних формах зупинилася доц. кафедри дитячих інфекційних хвороб ХМАПО В.Д. Макаренко. Щорічно реєструється більш ніж 10 млн випадків первинних поверхневих фрорм стрептококової інорекції та 10 тис. - інвазивної, які призводять до несприятливих наслідків: токсичного шоку (45 \%) та некротичного фрасциїту (25\%). Пізня діагностика стрептококової інсрекції на етапі надання амбулаторної допомоги, відсутність раннього призначення антибіотиків може призвести до розвитку інвазивних фрорм стрептококової інсрекції.

Підбиваючи підсумки конференції, профр. Л.А. Ходак зазначила, що сучасні вимоги до безперервної професійної освіти лікарів можуть бути реалізовані тільки через багатопланову діяльність кафедри: освітню, клінічну, наукову, методичну, впроваджувальну.

\section{REGIONAL SCIENTIFIC-PRACTICAL CONFERENCE «ACTUAL QUESTIONS OF INFECTIOUS DISEASES IN CHILDREN》 ON THE OCCASION OF 95-TH ANNIVERSARY OF THE KHARKIV MEDICAL ACADEMY OF POSTGRADUATE EDUCATION AND 25-TH ANNIVERSARY OF CHILDREN'S INFECTIOUS DISEASE DEPARTMENT}

\section{L.A. Khodak, V.I. Brailko}

Kharkiv Medical Academy of Postgraduate Education, Ukraine SUMMARY. The brief information about the scientificpractical conference «Actual problems of infectious diseases in children» is given on the occasion of the 95-th anniversary of the Kharkiv Medical Academy of Postgraduate Education and the 25-th anniversary of the Department of Children's Infectious Diseases, which took place on March 13, 2018 in Kharkiv.

Key words: scientific-practical conference; infectious diseases in children.

\section{Інорормація про авторів:}

Ходак Лариса Анатоліївна - д. мед. н., завідувач кафедри дитячих інсекційних хвороб Харківської медичної академії післядипломної освіти; e-mail: brailko04@gmail.com

Браілко Вікторія Ігорівна - к. мед. н., асистент кафедри дитячих інфекційних хвороб Харківської медичної академії післядипломної освіти; e-mail: brailko04@gmail.com

\section{Information about authors:}

Khodak Larysa - Doctor of Medicine, Head of the Department of Children's Infectious Diseases of Kharkiv Medical Academy of Postgraduate Education; e-mail: brailko04@gmail.com

Brailko Victoriya - Candidate of Medicine, assistant of the Department of Children's Infectious Diseases of Kharkiv Medical Academy of Postgraduate Education; e-mail: brailko04@gmail.com

Конорлікт інтересів: немає.

Authors have no conflict of interest to declare.

Отримано 12.06.2018 p. 